TAHKIM, Jurnal Peradaban dan Hukum Islam. Vol.4 No.l (Maret, 2021) | ISSN : 2597-7962

\title{
PELAKSANAAN PILKADA SERENTAK DI MASA PANDEMI COVID-19 PERSPEKTIF QAWAID FIQHIYYAH
}

\author{
Fachri Wahyudi, Muhammad Hanifannur \\ Magister Ilmu Agama Islam, Universitas Islam Indonesia \\ fachritahama@gmail.com
}

\begin{abstract}
ABSTRAK
Pilkada adalah salah satu perwujudan dari pelaksanaan kedaulatan rakyat dalam penyelenggaraan pemerintahan. Rakyat diberikan hak untuk aktif dalam menentukan pemimpinnya. Namun kali ini negara berada pada dua pilihan yang sulit, dimana pilkada serentak yang akan dilaksanakan pada tanggal 9 Desember 2020 menuai penolakan, mengingat kondisi Indonesia yang masih dilanda Pandemi covid-19 berdampak pada keselamatan rakyat Indonesia, dan disisi lain negara harus melaksanakan amanat konstitusi agar roda pemerintahan terus berjalan. Tujuan dari penelitian ini adalah untuk melihat pandangan qawaid fiqhiyyah mengenai pelaksanaan pilkada serentak di masa pandemi. Penelitian menggunakan metode hukum normatif yang bersifat kualitatif dan digali dari sumber-sumber kepustakaan (library reseach) yang terkait dengan obyek penelitian, serta menggunakan pendekatan deskriptif-normatif. Hasil penelitian menunjukan bahwa dampak yang ditimbulkan jika dilakukan pilkada serentak di masa pandemi covid-19 ini sangat beresiko, mengingat ada jutaan rakyat yang akan berpotensi terpapar covid-19, maka daripada itu menolak kemudharatan haruslah didahulukan dengan menunda kembali pilkada serentak demi menjaga jiwa (Hifdz An-Nafs) rakyat Indonesia dengan dasar kaidah "Menolak kemadharatan didahulukan daripada mengambil manfaat" dan kaidah fikih "Apabila ada dua kerusakan saling berlawanan, maka yang diperhatikan yang lebih besar bahayanya dengan melakukan yang lebih ringan bahayanya".
\end{abstract}

\section{Kata Kunci: Pilkada Serentak, Pandemi, Covid-19, Qawaid Fiqhiyyah.}

\begin{abstract}
Pilkada is one of the manifestations of the implementation of the people's sovereignty in the administration of government. People are given the right to be active in determining their leaders. But this time the country is in two difficult choices, where the simultaneous regional elections which will be held on December 9, 2020 are reaping rejection, considering that Indonesia's condition, which is still hit by the Covid-19 pandemic, has an impact on the safety of the Indonesian people, and on the other hand the country must carry out the constitutional mandate so that the wheels of government keep going. The purpose of this study is to see the views of qawaid fiqhiyyah regarding the implementation of simultaneous regional elections during a pandemic. This research uses normative legal methods that are qualitative in nature and extracted from literature sources (library
\end{abstract}


TAHKIM, Jurnal Peradaban dan Hukum Islam. Vol.4 No.l (Maret, 2021) | ISSN : 2597-7962

research) related to the object of research, as well as using a descriptive-normative approach. The research results show that the impact of simultaneous regional elections during the Covid-19 pandemic is very risky, considering that there are millions of people who will be exposed to COVID-19, so the agreement to reject harm must take precedence by returning the simultaneous regional elections for the sake of the soul (Hifdz An-Nafs) of the Indonesian people on the basis of the principle of "Refusing to take advantage first" and the rule of fiqh "If there are two opposing damages, then the one who is concerned is the greater the danger by doing the less dangerous".

\section{Keywords: simultaneous elections, Pandemic, Covid-19, Qawaid Fiqhiyyah.}

\section{A. PENDAhuluan}

Pada awal tahun 2020, seluruh dunia digemparkan dengan sebuah virus yang dalam penyebarannya sangat cepat. Transmisi virus ini terjadi antar manusia secara meluas dan cepat sehingga dikategorikan sebagai virus yang berbahaya, bahkan telah banyak memakan korban jiwa, sehingga membuat dunia lewat WHO (World Health Organization) sebuah organisasi kesehatan dunia dibawah naungan PBB mengumumkan keadaan ini sebagai pandemi global sejak 11 Maret 2020. Virus ini bernama Corona Virus Disease 2019 (Covid19) yang muncul pada akhir tahun 2019 di wuhan, China.

Berbagai upayapun telah dilakukan oleh berbagai negara dalam melawan virus ini, salah satunya lewat kebijakan lockdown dimana suatu negara menutup akses keluar masuk dengan negara lain dan memerintahkan masyarakatnya untuk berdiam di rumahnya masingmasing. Selain itu, kebijakan lain yang diterapkan adalah PSBB (Pembatasan Sosial Berskala Besar) dimana adanya pembatasan kegiatan penduduk dalam suatu wilayah yang terinfeksi covid-19. Tentunya hal ini menyebabkan adanya agenda berskala besar turut tertunda, diantaranya adalah Olimpiade Tokyo 2020 yang harus ditunda karena alasan pandemi, dan berbagai kegiatan kenegaraan lain yang sifatnya fundamental juga ikut ditunda. ${ }^{1}$ Selain itu, ada 55 negara yang akhirnya menunda pemilu nasional ataupun lokal serta referendum nasional, meski demikian ternyata ada 21 negara yang tidak menunda pemilu dan 9

\footnotetext{
${ }^{1}$ Richard Kennedy and Bonaventura Pradana Suhendarto, "Diskursus Hukum: Alternatif Pola Pengisian Jabatan Kepala Daerah di Masa Pandemi Covid-19," Jurnal Pembangunan Hukum Indonesia Vol. 2, No. 2 (Mei 2020), hlm. 189.
} 
TAHKIM, Jurnal Peradaban dan Hukum Islam. Vol.4 No.l (Maret, 2021) | ISSN : 2597-7962

diantaranya telah menyelenggarakan pemilunya ditengah pandemi covid-19. Salah satunya adalah Korea Selatan yang berhasil melaksanakan pemilu pada 15 April $2020 .^{2}$

Indonesia, negara yang juga ikut terdampak pandemi covid-19 mau tak mau juga ikut menunda berbagai agenda, salah satunya adalah penundaan pemilihan umum kepala daerah (Pilkada) yang rencana awalnya akan dilaksanakan pada 23 september 2020. ${ }^{3}$ Akhirnya dijadwal ulang menjadi tanggal 9 desember 2020. Tentunya hal ini menjadi perdebatan dalam masyarakat, mengingat jumlah kasus positif covid-19 terus bertambah dan jika pilkada tetap dilaksanakan sesuat jadwal tersebut maka akan memunculkan klaster baru penyebaran covid19 dan pastinya akan menambah kasus positif covid-19 di Indonesia dan mengancam jiwa masyarakat Indonesia.

Dalam Islam, pemeliharaan jiwa (hifz al-nafs) adalah suatu hal yang penting dalam ajaran agama Islam, hal ini sangat prioritas sehingga dalam suatu kasus diperbolehkan untuk memakan bangkai jika tidak ditemukan lagi makanan lain saat tersesat di hutan, dan diperbolehkan mengucapkan perkataan yang kufur apabila nyawa seseorang itu terancam. Hal ini menunjukkan bahwa suatu yang dilarang oleh syara' pada awalnya boleh dilakukan ketika dalam keadaan darurat. Begitupula sebaliknya, ibadah sholat berjamaah yang di wajibkan oleh umat Islam, kini harus di dilaksanakan di rumah masing-masing demi menjaga jiwa sebagaimana fatwa MUI Nomor 14 Tahun 2020 Tentang Penyelenggaraan Ibadah Dalam Situasi Terjadi Wabah Covid-19. ${ }^{4}$

\section{B. METODE PENELITIAN}

Jenis penelitian yang dipakai dalam penelitian ini adalah penelitian hukum normatif yang bersifat kualitatif dan digali dari sumber-sumber kepustakaan (library reseach) yang terkait dengan obyek penelitian. Metode penelitian hukum normatif adalah penelitian hukum yang meletakkan hukum sebagai sebuah bangunan sistem norma. Sistem norma yang dimaksud adalah mengenai asas-asas, norma, kaidah dari perundang-undangan, putusan

\footnotetext{
${ }^{2}$ Ibid.

${ }^{3}$ Berdasarkan Pasal 201 ayat (6) Undang-Undang Nomor 10 Tahun 2016 Tentang Pemilihan Umum.

${ }^{4}$ Abdur Rahman Adi Saputera, "Menelisik Dinamika dan Eksistensi Fatwa MUI Sebagai Upaya Mitigasi Pandemi COVID-19,” Tahkim (Jurnal Peradaban dan Hukum Islam) Vol.3, No. 2 (Oktober 2020), hlm. 70.
} 
pengadilan, perjanjian serta doktrin (ajaran). ${ }^{5}$ Sedangkan untuk pendekatan yang digunakan dalam penelitian ini adalah menggunakan pendekatan deskriptif-normatif, deksriptif disini digunakan untuk mendeskripsikan pelaksanaan pemilihan kepala daerah serentak yang dilaksanakan oleh Pemerintah Indonesia bertujuan agar menjamin hak konstitusional rakyat untuk memilih dan dipilih disamping menjalankan amanah konstitusi, serta agar roda pemerintahan daerah tetap berjalan, namun disisi lain perlindungan terhadap warga negara juga sangat perlu diperhatikan, mengingat gelombang positif covid-19 juga terus meningkat tajam bahkan membuat Presiden menerbitkan Keputusan Presiden Nomor 12 Tahun 2020 Tentang Penetapan Bencana Nonalam Penyebaran Corona Virus Disease 2019 (COVID-19) Sebagai Bencana Nasional. Sedangkan pendekatan normatif adalah suatu metode pendekatan dalam penelitian yang memandang suatu permasalahan berdasarkan legal formal, yaitu suatu anjuran yang terkandung dalam nas yang berhubungan dengan halal, haram, boleh atau tidak dan sejenisnya. ${ }^{6}$ Dalam hal ini dilakukan dengan melihat nilai-nilai dari qawaid fiqhiyyah mengenai pelaksanaan pilkada serentak di tengah pandemi covid-19. Penelitian ini mengambil sumber data primer dan data sekunder sebagai pendukung diantaranya perundang-undangan, jurnal, dan kitab qawaid fiqhiyyah dan dari data yang terkumpul lewat dokumen-dokumen serta realita sosial di tengah masyarakat inilah penulis menganalisa melalui Deskriptive Analytic Method Content sebagai pisau analisis. Dan kesimpulan yang didapatkan melalui metode berpikir yang menarik kesimpulan dari hal-hal yang bersifat khusus menjadi umum (induktif) serta lewat metode menarik kesimpulan dari hal-hal umum menjadi khusus (deduktif). ${ }^{7}$

\section{PEMBAHASAN}

\section{Pemilihan Kepala Daerah Serentak}

Pemilihan umum atau disingkat dengan Pemilu, adalah salah satu sarana untuk mewujudkan kedaulatan rakyat dalam kehidupan bernegara. Sebagai negara demokrasi,

\footnotetext{
5 Mukti Fajar ND and Yulianto Achmad, Dualisme Penelitian Hukum Normatif Dan Empiris (Yogyakarta: Pustaka Pelajar, 2010), hlm. 34.

${ }^{6}$ Khoiruddin Nasution, Pengantar Studi Islam (Yogyakarta: Academia+TAZAFFA, 2007), hlm. 149.

${ }^{7}$ Noer Muhajir, Metodologi Penelitian Kuantitatif (Yogyakarta: Percetakan Raka Sarasin, 2016), hlm. 76-77.
} 
TAHKIM, Jurnal Peradaban dan Hukum Islam. Vol.4 No.l (Maret, 2021) | ISSN : 2597-7962

Indonesia memberikan peluang untuk seseorang memilih ataupun dipilih dalam pemilihan umum. Sebagai sarana sekaligus sebagai ukuran dilaksanakan atau tidaknya kedaulatan rakyat, hakikat pemilihan umum adalah sebagai pengakuan atas keberadaan hak memilih dan menentukan pilihannya secara bebeas dalam proses pemilihan dan hak untuk dipilih setiap warga negara untuk berkesempatan yang adil dalam menjadi anggota DPR, DPD, Presiden dan Wakil Presiden, DPRD dan kepala daerah. ${ }^{8}$

Dalam Pasal 22E ayat (2) UUD 1945 dijelaskan bahwa: Pemilihan umum diselenggarakan untuk memilih anggota Dewan Perwakilan Rakyat, Dewan Perwakilan Daerah, Presiden dan Wakil Presiden dan Dewan Perwakilan Rakyat Daerah, yang dilaksanakan secara langsung, umum, bebas, rahasia, jujur, dan adil setiap lima tahun sekali. Selain itu, dalam Pasal 14 ayat (4) UUD 1945 dijelaskan juga bahwa: Gubernur, Bupati dan Walikota masing-masing sebagai kepala pemerintahan daerah provinsi, kabupaten, dan kota dipilih secara demokratis. Serta lewat UU No. 32 Tahun 2004 Tentang Pemerintahan Daerah diatur mengenai pemilihan kepala daerah dan wakil kepala daerah yang dipilih secara langsung oleh rakyat yang diajukan oleh partai politik atau gabungan partai politik.

Perlu diketahui bahwa Indonesia memiliki sejarah panjang dalam pemilihan umum. Secara singkat, sejarah dimulai pertama kali dan dilaksanakan pada tahun 1955 yang mana menghasilkan lembaga negara dengan otoritas membentuk konstitusi baru Indonesia dan DPR. Berlanjut pada masa Orde Baru, pada tahun 1971 pemilu dilaksanakan dengan golkar sebagai pemenang pemilu tahun 1971, dan pemilu terus berlanjut beberapa kali dalam kancah politik Indonesai (Pemilu tahun 1971, 1977, 1982, 1992) dengan hasil yang sama hingga tahun 1997. Akan tetapi, kemenangan yang diraih oleh partai golkar ini ternyata diwarnai oleh berbagai kecurangan, seperti manipulasi oleh pemerintah, tekanan birokrasi, monopoli media, hingga lembaga penyelenggara yang tidak adil demi melindungi kepentingan pemerintahan orde baru. ${ }^{9}$

\footnotetext{
${ }^{8}$ Khairul Fahmi, "Pergeseran Pembatasan Hak Pilih dalam Regulasi Pemilu dan Pilkada," Jurnal Konstitusi Vol.14, No. 4 (Februari 2018), hlm. 750.

${ }^{9}$ Yuliani Widianingsih, "Demokrasi dan Pemilu di Indonesia: Suatu Tinjauan Dari Aspek Sejarah dan Sosiologi Politik, ” Jurnal Signal Vol.5, No. 2 (Desember 2017), hlm. 9.
} 
TAHKIM, Jurnal Peradaban dan Hukum Islam. Vol.4 No.l (Maret, 2021) | ISSN : 2597-7962

Kemudian berlanjut pada pemilu tahun 1999, merupakan pemilu yang berbeda dari tahun-tahun sebelumnya pada masa Orde Baru, meskipun situasi politik masih sangat dipengaruhi oleh kekuatan Orde Baru. Selanjutnya pada pemilu tahun 2004 mengalami perubahan, dimana masyarakat memilih langsung tiga macam institusi yakni anggota DPR termasuk di tingkat pusat, provinsi dan kabupaten/kota, Presiden dan Wakil Presiden, serta anggota DPD yang dilaksanakan secara serentak di Indonesia. Dan pemilu tahun 2004 ini menjadi pemilu kedua yang dianggap paling demokratis setelah runtuhnya era Suharto.dan kesuksekan pemilu ini juga berlanjut ditahun berikutnya yaitu pemilu 2009 dan pemilu 2014 serta pemilu tahun 2019 .

Mengenai pemilihan kepala daerah (Pilkada), dalam pelaksanaannya baru dimulai sejak di sahkannya UU No. 32 Tahun 2004 Tentang Pemerintahan Daerah serta diterbitkannya PP No. 6 Tahun 2005 tentang Pemilihan, Pengesahan, Pengangkatan, dan Pemberhentian Kepala Daerah dan Wakil Kepala Daerah, maka sejak itu Kepala Daerah dan Wakil Kepala Daerah dipilih langsung oleh rakyat, dan pemilihan langsung Kepala Daerah dan Wakil Kepala Daerah pertama kali dilaksanakan pada pemilihan Kepala Daerah dan Wakil Kepala Daerah kabupaten Kutai Kartanegara, Kalimantan Timur pada juni 2005.

Pemilu dan Pilkada adalah salah satu perwujudan dari pelaksanaan kedaulatan rakyat didalam penyelenggaraan pemerintah, dimana rakyat diberikan hak untuk aktif dalam menentukan pemimpinnya. hal ini merupakan amanat dari Pasal 1 Ayat (2) UUD 1954 yang menjeaskan bahwa "Kedaulatan berada ditangan rakyat dan dilaksanakan menurut UndangUndang Dasar". Dinamakan sebagai pesta demokrasi, sebab merupakan gambaran besar bahwa ini adalah pesta yang ditujukan kepada rakyat untuk memilih ataupun mengusung kontestan yang menurut mereka pantas untuk menduduki jaban atas nama rakyat atau menjadi pemimpin yang dipilih oleh rakyat yang dianggap pantas dan dipercayai rakyat. ${ }^{10}$

Pada awalnya pilkada dilaksanakan sendiri-sendiri, artinya setiap daerah melaksanakan pilkada sesuai dengan masa jabatan yang ada, namun pada tahun 2015

\footnotetext{
${ }^{10}$ R. Sacipto, “Tinjauan Wawasan Kaum Milineal Menghadapi Pelaksanaan Pesta Demokrasi, ” $A D I L$ Indonesia Journal Vol. 1, No. 1 (February 2019), hlm. 62.
} 
TAHKIM, Jurnal Peradaban dan Hukum Islam. Vol.4 No.l (Maret, 2021) | ISSN : 2597-7962

pemerintah melaksanan pemilihan kepala daerah serentak. Hal berdasarkan UU No. 8 Tahun 2015 Tentang Perubahan Atas UU No. 1 Tahun 2015, pasal 3 ayat (1) menjelaskan bahwa "Pemilihan dilaksanakan setiap 5 (lima) tahun sekali secara serentak di seluruh Wilayah Kesatuan Republik Indonesia", hal ini bertujuan agar pemilihan kepala daerah dilaksanakan serentak dan terciptanya efektifitas serta efisiensi anggaran, mengingat Indonesia adalah negara yang luas terdiri dari 34 Provinsi, 416 kabupaten dan 98 kota.

Pilkada serentak pertama dilaksanakan pada 9 Desember 2005 yang diikuti oleh 9 Provinsi, 34 Kota dan 224 Kabupaten. Kemudian pilkada serentak kedua dilaksanakan pada 15 Februari 2017 yang diikuti oleh 7 Provinsi, 18 Kota dan 76 Kabupaten. Pilkada serentak ketiga dilaksanakan pada 27 Juni 2018 yang diikuti oleh 17 Provinsi, 39 Kota dan 115 Kabupaten. Serta pelaksanaan pilkada ke empat akan dilaksanakan pada tahun 2020, 2022 dan 2023 sehingga pada tahun 2027 akan dilaksanakan pilkada serentak nasional yang meliputi seluruh wilayah Indonesia. ${ }^{11}$

Pilkada serentak adalah upaya untuk menciptakan local accountability, political equity dan local responsivenesess. Dengan demikian, demokrasi ditingkat lokal terkait erat dengan tingkat partisipasi dan relasi kuasa yang dibangun atas dasar pelaksanaan azas kedaulatan rakyat. Selain itu juga mampu mengantarkan masyarakat pada kondisi sosial, politik dan ekonomi yang lebih baik, tentunya pilkada yang baik akan menghasilkan pemimpin yang baik pula dan pilkada yang diselenggarakan secara lebih profesional, demokratis, akan memberikan dampak nyata terhadap perubahan politik. ${ }^{12}$

Pada pilkada serentak tahun 2020 ini, mulanya pemerintah telah menetapkan bahwa pelaksanaan pilkada serentak akan dilaksanakan pada 23 September 2020 yang diikuti oleh 9 Provinsi, 224 Kabupaten dan 37 Kota. Akan tetapi pada tanggal 2 Maret 2020, pemerintah mengumumkan dua kasus pertama covid-19 yang selanjutnya terus bertambah hingga hari ini. Tentunya dengan keadaan negara yang sedang dilanda pandemi covid-19 ini akhirnya

11 Achmad Arifulloh, "Pelaksanaan Pilkada Serentak Yang Demokratis, Damai, Dan Bermartabat," Jurnal Pembaharuan Hukum Vol. 3, No. 3 (2016), hlm. 302.

12 Ibid. 
TAHKIM, Jurnal Peradaban dan Hukum Islam. Vol.4 No.l (Maret, 2021) | ISSN : 2597-7962

pemerintah menunda jadwal pelaksanaan pesta demokrasi ini dengan dasar Undang-Undang No. 6 Tahun 2020 Tentang Penetapan Peraturan Pemerintah Pengganti Undang-Undang, di dalam pasal 120 ayat (1) dijelaskan bahwa "Dalam hal pada sebagian wilayah Pemilihan, seluruh wilayah Pemilihan, sebagian besar daerah, atau seluruh daerah terjadi kerusuhan, gangguan keamanan, bencana alam, bencana nonalam, atau gangguan lainnya yang mengakibatkan sebagian tahapan penyelenggaraan Pemilihan atau Pemilihan serentak tidak dapat dilaksankan, dilakukan pemilihan lanjutan atau pemilihan serentak lanjutan”.

Akan tetapi, kebijakan pemerintah terhadap pilkada serentak ini menuai berbagai komentar, bahkan penolakan. Hal ini disebabkan pemerintah menjadwalkan ulang pilkada serentak pada tanggal 9 Desember 2020, dimana selisih dari jadwal awal hanya 3 (tiga) bulan saja, selain itu mengingat hingga sampai saat ini kasus positif covid-19 kian hari terus bertambah sehingga banyak yang berpendapat bahwa pelaksanaan pilkada serentak pada bulan desember ini tidak tepat dan dapat memunculkan klaster baru penyebaran covid-19, karena memunculkan keramaian.

Sebelumnya, menanggapi covid-19 ini, Hai'ah Kibar Al-Azhar Ulama juga menanggapi terkait keadaan darurat yang disebabkan oleh virus covid-19 dengan memberikan sejumlah pernyataan, salah satunya adalah anjuran agar melindungi dan menjaga jiwa, serta mencegah semua hal-hal berbahaya yang merupakan hal pokok dalam prinsip maqashid syariah. Hal ini juga dilakukan oleh Majelis Ulama Indonesia (MUI), lewat Fatwa MUI No. 14 Tahun 2020 dalam poin pertama ketentuan hukum bahwa setiap orang wajib melakukan ikhtiar menjaga kesehatan dan menjauhi setiap hal yang dapat menyebabkan terpapar penyakit, karena hal itu merupakan bagian dari menjaga tujuan pokok beragama (al-Dharuriyat al-Khams), dengan tetap melaksanakan pilkada serentak ini, poinpoin dalam fatwa itu terlanggar.

Alasan penolakan tidak hanya sebatas komentar belaka mengingat pelaksanaan pilkada dimasa pandemi covid-19 sangat berisiko tinggi. Sebagaimana yang terjadi pada negara tetangga Indonesia, Malaysia. Malaysia, tepatnya di negara bagian Sabah yang merupakan negara bagian terbesar kedua di Malaysia. Pada 9 September 2020 yang lalu, 
negara bagian Sabah melakukan pemilu atau Pemilihan Raya Negeri (PRN) yang berdampak memunculkan klaster baru penyebaran covid-19. Setelah pemilu Sabah selesai, kasus covid19 melonjak drastis, terkonfirmasi sebanyak 488 kasus covid-19 di Sabah yang menyebabkan Sabah masuk zona merah covid-19. Tentunya hal ini membuat semua pihak sadar bahwa Malaysia yang awalnya lebih dulu melonggarkan aturan sosilanya dimana warga negaranya sudah bisa berlibur leluasa, sekolah kembali dibuka, dan kegiatan perniagaan sudah jauh lebih longgar dibanding awal ketika covid-19 menyerang kini harus melakukan lockdown kembali di negara bagian Sabah sebagai langkah memutus rantai penyebaran covid-19. ${ }^{13}$

\section{Pilkada Serentak Dimasa Pandemi Covid-19 Perspektif Qawaid Fiqhiyyah}

Menurut Ahmad Warson Munawwir, qawaid adalah al-asas (dasar, asas dan pondasi), al-qanun (peraturan kaidah dasar), al-mabda' (prinsip), dan al-nasaq (metode dan cara). ${ }^{14}$ Kata kaidah, tidak hanya ada pada satu disiplin ilmu saja, akan tetapi ada dalam berbagai disiplin ilmu, seperti ilmu Bahasa, ilmu Tafsir dan lain sebagainya. Para fuqaha mengembangkan istilah kaidah untuk pengembangan capukan suatu hukum dalam ilmu hukum dengan dua istilah, yakni qawaid fiqhiyyah dan qawaid ushuliyyah. Perbedaan antara qawaid fiqhiyyah dan qawaid ushuliyyah adalah qawaid fiqhiyyah merupakan generalisasi hukum fikih yang telah dirumuskan dalam bentuk proporsi-proporsisedangkan qawaid ushuliyyah adalah generalisasi bentuk-bentuk dan makna-makna lafaz dalam Al-Qur'an dan Sunnah baik yang terumuskan dalam proporsi itu atau tidak.

Mengenai qawaid fiqhiyyah (kaidah fikih), dijelaskan menurut Hasbi Ash-Shiddiqy bahwa qawaid fiqhiyyah adalah hukum yang sifatnya umum, diambil dari dalil-dalil umum dari nas yang menjadi pokok-pokok kaidah-kaidah kulliyah yang bisa disesuaikan dengan banyak juz 'iyyah sebagaimana yang dimaksud syara' dalam meletakkan mukallaf dibawah bebanan taklif dan untuk memahami rahasia tasyri dan hikmah yang terkandung

${ }^{13}$ https://republika.co.id/berita/qi2wlw328/pelajaran-dari-klaster-pemilu-sabah diakses pada hari Selasa tanggal 13 Oktober 2020 pukul 10.36 WIB

14 Ahmad Warson Munawwir, Al-Munawwir (Kamus Arab-Indonesia) (Surabaya: Pustaka Progresif, 1989), hlm. 1224. 
TAHKIM, Jurnal Peradaban dan Hukum Islam. Vol.4 No.l (Maret, 2021) | ISSN : 2597-7962

didalamnya. ${ }^{15}$ Dapat disimpulkan bahwa kaidah fikih adalah hukum yang bersifat umum (menyeluruh) yang teraplikasi pada seluruh bagiannya atau sebagaian besarnya agar dapat diketahui hukum-hukumnya.

Mengenai qawaid fiqhiyyah ini memiliki peranan yang signifikan dan urgen dalam pemeliharaan dan pengembangan hukum Islam. Pertama, qawaid fiqhiyyah bisa dijadikan referensi oleh ahli untuk memudahkan dalam menyelesaikan masalah fikih yang terjadi saat ini dengan mengkategorikan masalah-masalah yang serupa dalam lingkup satu kaidah. Kedua, qawaid fiqhiyyah sebagai alat atau media dalam menafsirkan nas dalam hal instimbat hukum, terutama yang termasuk dalam kategori ma lam yu'lam min ad-din bi ad-dharurah (hukum-hukum yang tidak diterangkan secara tegas dalam nas karena dalilnya masih bersifat zanni). Ketiga, fikih itu adalah sebuah pengetahuan untuk dapat melakukan persamaanpersamaan suatu permasalahan dengan masalah lain yang serupa. Sehingga bisa dikatakan bahwa qawaid fiqhiyyah masih tetap urgen untuk dijadikan sebagai pedoman dalam menyelesaikan suatu permasalahan yang ada dan sifatnya kontemporer, meskipun ada beberapa qawaid fiqhiyyah yang masih menjadi perdebatan para ulama. Singkatnya qawaid fiqhiyyah berperan sebagai panduan yang lebih praktis yang diturunkan dari teks dan jiwa nash dan telah digeneralisasikan oleh para ulama-ulama terdahulu lewat berbagai permasalahan fikih yang dahulu pernah terjadi, sehingga saat ini mudah diterapkan dan dipelajari oleh masyarakat Islam secara luas. ${ }^{16}$

Metode yang digunakan para ahli hukum Islam dalam perumusan kaidah-kaidah fikih adalah dengan metode penalaran Induktif, induksi adalah metode penarikan kesimpulan berdasarkan keadaan-keadaan yang khsusus untuk diperlakukan secara umum. Para ahli ushul fikih meneliti ayat al-Quran dan Sunnah Rasul dengan tujuan untuk menggali nilainilai serta norma-norma yang ada didalamnya yang kemudian akan dirumuskan suatu kaidah fikih dalam bentuk proporsi yang sempurna walaupun terkadang sederhana, selain itu mereka

15 Muhammad Iqbal, "Urgensi Kaidah-Kaidah Fikih Terhadap Reaktualisasi Hukum Islam Kontemporer, ” EduTech: Jurnal Ilmu Pendidikan Dan Ilmu Sosial Vol. 4, No. 2 (October 2018), hlm. 21-22.

${ }^{16}$ Iwan Permana, "Penerapan Kaidah-Kaidah Fiqih Dalam Transaksi Ekonomi di Lembaga Keuangan Syariah," Tahkim (Jurnal Peradaban dan Hukum Islam) Vol. 3, No. 1 (March 2, 2020), hlm. 18. 
TAHKIM, Jurnal Peradaban dan Hukum Islam. Vol.4 No.l (Maret, 2021) | ISSN : 2597-7962

juga meneliti terhadap hukum dan masalah fikih yang kemudian dirumuskan suatu kaidah fikih. Sehingga dari metode ini banyak menghasilkan kaidah fikih, diantaranya kaidah: alUmur bi Maqasidiha yang disarikan dari beberapa ayat dalam al-Quran seperti Surah alBayyinah ayat 5, surah Ali-Imran ayat 145, serta Hadis Nabi: "Amal-amal itu hanyaah dengan niat”. Sehingga terbentuklah kaidah fikih seperti itu. begitupula dengan kaidah fikih lainnya. $^{17}$

Dengan berbagai metode perumusan qawaid fiqhiyyah ini maka dihasilkan berbagai kaidah-kaidah fikih yang disusun dalam dua bagian, yakni kaidah-kaidah fikih induk (alqawaid al-asasiyah), dinamakan induk karena dari kaidah-kaidah inilah terciptanya kaidah yang kedua, yakni kaidah-kaidah cabang baik yang disepakati ulama dan yang diperselisihkan ulama. Kaidah-kaidah fikih induk ini pada umumnya berjumlah 5 (lima) kaidah. Dan dari lima kaidah fikih Induk inilah nantinya akan muncul kaidah fikih cabang yang jumlahnya sangat banyak. Dimana lima kaidah induk itu adalah sebagai berikut: ${ }^{18}$

1) Kaidah Induk Pertama

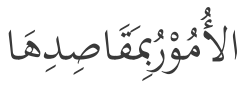

Artinya: segala sesuatu perkara tergantu dengan niatnya

Kaidah ini bermaksud bahwa setiap sesuatu itu dilaksanakan sesuai dengan niatnya, yakni ikhlas karena Allah. Sehingga setiap urusan yang niatnya kepada Allah atau untuk ibadah, maka ia akan memperoleh pahala dan keridhaan Allah, namun jika niatnya bukan karena Allah dan justru karena keterpaksaan, riya’ maka ia tidak akan mendapatkan pahala dari Allah.

2) Kaidah Induk Kedua

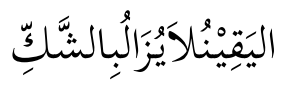

${ }^{17}$ Duski Ibrahim, Al-Qawa'id Al-Fiqhiyah (Kaidah-Kaidah Fiqih) (Palembang: Noerfikri, 2019), hlm. 41.

${ }^{18}$ Ibid. 
TAHKIII, Jurnal Peradaban dan Hukum Islam. Vol.4 No.l (Maret, 2021) | ISSN : 2597-7962

\section{Artinya: keyakinan tidak bisa dihilangkan dengan keragu-raguan}

Kaidah ini bermaksud bahwa segala sesuatu yang dikerjakan (beramal) harus dilakukan dengan penuh keyakinan, dan keragu-raguan tidak dapat menghilangkan keyakinan itu. artinya setiap perkara yang tetap tidak akan berubah dengan sebab kedatangan bukti yang terdapat syak (ragu-ragu) padanya.

3) Kaidah Induk Ketiga

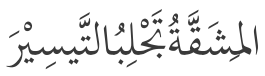

Artinya: kesulitan menyebabkan kemudahan

Maksud dari kaidah ini adalah hukum syari'ah didasarkan atas kenyamanan, keringanan dan menghilangkan kesulitan, sehingga apabila hukum-hukum yang dalam penerapannya menimbulkan kesulitan terhadap mukallaf, maka syari'ah meringankan agar sesuatu itu bisa dilaksanakan oleh mukallaf.

4) Kaidah Induk Keempat

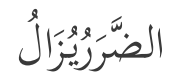

Artinya: kemudaratan dihilangkan

Kaidah ini bermaksud bahwa setiap kemudaratan (membahayakan) harus dihilangkan, dharar adalah kesulitan yang dapat mengancam eksistensi manusia, jika tak diselesaikan maka akan berdampak pada kelangsungan agama, jiwa, nasab, harta serta kehormatan manusia terancam, sehingga kebolehan berbuat atau meninggalkan sesuatu karena ada unsur dharar boleh dilakukan selama masih terdapat bahaya.

5) Kaidah Induk Kelima

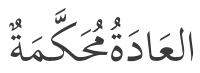

Artinya: adat kebiasaan itu bisa ditetapkan sebagai hukum

Maksud dari kaidah ini adalah bahwa adat bisa dijadikan sebagai hukum selama tidak bertentangan dengan syari'at islam karena adat sangat berperan dalam pembentukan dan 
TAHKIM, Jurnal Peradaban dan Hukum Islam. Vol.4 No.l (Maret, 2021) | ISSN : 2597-7962

perkembangan hukum Islam, banyak sekali andil adat dalam terbentuknya berbagai aliran hukum dalam sejarah. ${ }^{19}$

Mengenai Pilkada, jelaslah bahwa tujuan dari pilkada ini adalah baik, apalagi negara Indonesia merupakan negara demokrasi sehingga dalam pelaksanaannya dilakukan pemilihan guna memilih para pemimpin yang akan menduduki jabatan sebagai kepala daerah baik ditingkat kabupaten dan kota ataupun tingkat provinsi untuk mengemban amanah rakyat sesuai dengan tugas-tugasnya berdasarkan peraturan perundang-undangan yang ada. ${ }^{20}$ Selain itu melalui pilkada ini memberikan kebebasan kepada rakyat agar bisa memilih secara langsung para pemimpin daerahnya sesuai dengan hati nuraninya masing-masing dan harus dilakukan dengan benar dan sesuai dengan peraturan yang ada.

Apalagi mayoritas dari penduduk Indonesia adalah bergama Islam, sehingga dalam pilkada ini haruslah memilih sosok pemimpin yang ideal dan sempurna, meski memang untuk sekarang sulit mencari sosok yang memiliki kriteria seperti itu, namun paling tidak ada upaya untuk mendekati yang terbaik dan setidaknya seorang pemimpin yang dipilih setidaknya memiliki sifat-sifat kepemimpinan seperti sosok Nabi Muhammad SAW sebagi Insal Kamil.

Tentunya dalam pilkada serentak tahun 2020 ini masyarakat harus memilih para pemimpinnya yang akan memimpin daerahnya masing-masing, dari 34 provinsi yang ada, pilkada serentak 2020 akan memilih pemimpin-pemimpin dengan jumlah 9 Provinsi, 224 Kabupaten dan 37 Kota, artinya ada sebanyak 270 pemimpin yang akan dipilih di masingmasing wilayahnya yang mengadakan pilkada serentak ini.

Namun, pelaksanaan pilkada serentak di tengah pandemi covid-19 ini tentunya menimbulkan berbagai penolakan terutama mengenai keselamatan rakyat ditengah pandemi covid-19, di dalam maqashid syari'ah dijelaskan bahwa pentingnya menjaga agama (Hifdz Ad-Din), menjaga jiwa (Hifdz An-Nafs), menjaga akal (Hifdz Al'Aql), menjaga keturunan

\footnotetext{
${ }^{19}$ Fathurrahman Azhari, Qawaid Fiqhiyyah Muamalah, (Banjarmasin: Lembaga Pemberdayaan Kualitas Ummat Banjarmasin, 2015), hlm. 122.

${ }^{20}$ Undang-Undang Nomor 23 Tahun 2014 Tentang Pemerintah Daerah.
} 
TAHKIM, Jurnal Peradaban dan Hukum Islam. Vol.4 No.l (Maret, 2021) | ISSN : 2597-7962

(Hifdz An-Nashb) serta menjaga harta (Hifdz Al-Maal). Selain itu dalam kaidah-kaidah fikih induk (al-qawaid al-asasiyah) dijelaskan bahwa الضَّرَرِيُرَالُ yang artinya kemudharatan hendaknya dihilangkan. Pandemi covid-19 sangat berbahaya dan sampai saat ini meskipun pemerintah tengah menyiapkan vaksin covid-19 akan tetapi sampai saat ini belum ada vaksin yang ampuh untuk melawan virus covid-19, selain itu covid-19 ini dalam penyebarannya antar sesama manusia sangat cepat, sehingga pemerintah pun melakukan pencegahan dan memutus mata rantai penyebaran virus covid-19 lewat kebijakan physical distancing atau menjaga jarak.

Tentunya ketika pilkada serentak dilaksanakan akan menimbulkan keramaian masyarakat di tempat pemungutan suara, apalagi pilkada serentak ini tidak hanya dilaksanakan di satu daerah saja, melainkan 270 daerah yang tersebar di seruluh Indonesia, dan ini akan menimbulkan klaster baru penyebaran covid-19 dan pastinya jumlah positif covid-19 akan bertambah drastis. Dalam hal ini tentunya pendekatan qawaid fiqhiyyah diperlukan, ada kaidah fikih yang berbunyi:
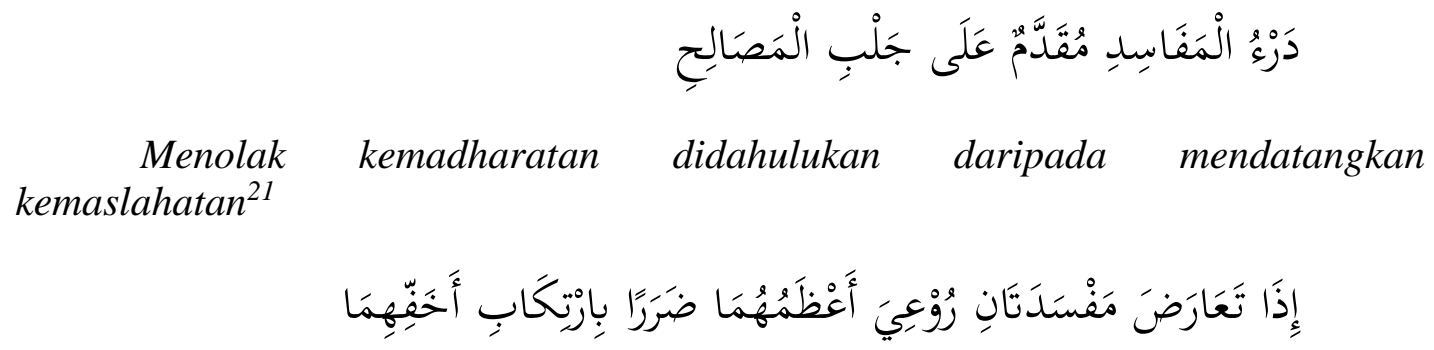

Apabila ada dua kerusakan saling berlawanan, maka yang diperhatikan yang lebih besar bahayanya dengan melakukan yang lebih ringan bahayanya. ${ }^{22}$

Dalam hal pilkada serentak dimasa pandemi covid-19 ini tentunya haruslah bersikap bijaksana. Memang pilkada serentak adalah sesuatu hal yang harus dilaksanakan dalam negara demokrasi agar tidak ada kekosongan dalam jabatan kepala daerah, sehingga pelayanan pemerintah kepada rakyat tetap berajalan, akan tetapi dampak yang ditimbulkan

${ }^{21}$ Duski Ibrahim, Al-Qawa'id..., hlm. 84.

${ }^{22}$ Abdul Karim Zaidan, Al- Wajiz 100 Kaidah Fikih Dalam Kehidupan Sehari-Hari, Terj. Muhyidin Mas Rida (Jakarta: Pustaka al-Kautsar, 2008), hlm. 156. 
jika tetap melakukan pilkada serentak di masa pandemi covid-19 ini tidak main-main, mengingat ada jutaan rakyat yang akan beresiko terpapar covid-19 maka daripada itu menolak kemudharatan haruslah didahulukan dengan menunda kembali pilkada serentak dan akibat yang ditimbulkan dari penundaan pilkada serentak tidak lebih besar daripada tetap melaksanakan pilkada serentak di tengah pandemi covid-19 ini, penundaan pelaksanaan pilkada serentak adalah demi menjaga jiwa (Hifdz An-Nafs) rakyat Indonesia.

Jika pilkada serentak pada tanggal 9 Desember 2020 ini ditunda kembali, ada beberapa opsi yang bisa dijadikan solusi dalam permasalahan pilkada serentak di tengah pandemi covid-19 ini, di antaranya: ${ }^{23}$

\section{Penunjukan Pelaksana Tugas}

Opsi pertama adalah dengan Penunjukan Pelaksana Tugas (Plt) sebagai solusi mengisi kekososngan jabatan. Opsi ini juga sudah dilakukan pada pilkada sebelumnya begitu juga dengan pilkada serentah tahun 2020, dimana Plt yang ditunjuk oleh Menteri Dalam Negeri (Mendagri) merupakan seorang pejabat, dalam hal ini untuk mengisi kekosongan jabatan Gubernur di isi oleh pejabat dengan jabatan pimpinan tinggi madya, sedangkan untuk jabatan Bupati/Walikota di isi oleh pejabat dengan jabatan pimpinan tinggi pratama, pengisian kekosongan jabatan kepala daerah oleh Penunjukan Pelaksana Tugas (Plt) berlangsung hingga pelantikan kepala daerah tetap hasil pilkada serentak.

Meski ini menjadi solusi, akan tetapi kewenangan Plt terbatas sesuai Pasal 132A PP No. 49 Tahun 2008, serta plt tidak memiliki kewenangan untuk mengambil keputusan maupun kebijakan strategis sehingga berakibat pada terganggunya roda pemerintahan daerah serta perkembangan daerah. Selain itu, jika covid-19 masih terus berlangsung dan jabatan Plt diperpanjang maka akan berdampak pada sisi politis, dimana Kepala daerah yang terpilih nanti tidak dapat menjalankan jabatannya selama 5 tahun penuh, karena sebagian waktunya telah dipakai oleh Plt akibat penundaan pilkada serentak.

\footnotetext{
${ }^{23}$ Richard Kennedy dan Bonaventura Pradana Suhendarto, Diskursus..., Hlm. 192.
} 
TAHKIM, Jurnal Peradaban dan Hukum Islam. Vol.4 No.l (Maret, 2021) | ISSN : 2597-7962

2. Pemilihan Kepala Daerah Secara Tidak Langsung

Untuk opsi kedua ini sebenarnya bukan opsi baru, mengingat opsi ini telah dipakai oleh pemerintah pada tahun-tahun sebelumnya. Pemilihan Kepala Daerah Secara Tidak Langsung merupakan sistem pemilihan kepala daerah yang dipilih oleh DPRD atau yang dikenal dengan sistem perwakilan. Tentunya opsi ini bisa dilakukan demi memilih kepala daerah agar tidak terjadi kekosongan jabatan, dan tentu saja tidak mengeluarkan biaya yang besar dibanding pilkada langsung serta tidak begitu mengancam akibat kondisi pandemi covid-19.

Namun tentu saja opsi ini memiliki kekurangan, dimana akan menciderai demokrasi di Indonesia, karena rakyat tidak dapat memilih langsung pemimpin daerahnya, hanya diwakilkan oleh DPRD, sehingga ada ketidakpuasan rakyat dalam hal ini.

\section{Pemilihan Kepala Daerah Dengan Menggunakan Sistem Elektronik}

Untuk opsi ketiga ini memungkinkan rakyat untuk memilih langsung kepala daerahnya ditengah pandemi covid-19. Opsi ini juga menjadi salah satu solusi dalam memilih kepala daerah, hal ini dikarenakan perkembangan tekhnologi informasi dan komunikasi yang canggih. Pemilihan kepala daerah bisa dilaksanakan dari rumah masing-masing lewat tekhnologi yang ada, seperti smarphone misalanya. Tentunya pemilihan kepala daerah menggunakan sistem elektronik memiliki keungulan selain bisa dilaksanakan dalam kondisi pandemi, diantaranya hemat biaya, sederhana dan efisien, waktu yang lebih fleksibel dan efektif, akurasi dalam penghitungan suara, meminimalisirkan terjadinya kecurangan serta lebih ramah lingkungan.

Akan tetapi pelaksanaan pilkada serentak lewat sistem elektronik ini perlu persiapan yang matang, mengingat tidak semua daerah di Indonesia terhubung dengan sitem elektronik ini, masih banyak rakyat yang hidup di pedalaman dan pelosok yang belum lancar akan tekhnologinya, selain infrastruktur fisik ini juga 
TAHKIM, Jurnal Peradaban dan Hukum Islam. Vol.4 No.l (Maret, 2021) | ISSN : 2597-7962

perlu pembanguan insfrakturtur legal beruapa hukun dan aturan terkait pilkada elektronik.

Itulah beberapa opsi yang bisa dipakai oleh pemerintah dalam mengahadapi pilkada serentak 2020 di tengah pandemi covid-19 ini, meski setiap opsi memiliki kekurangan tersendiri, setidaknya tidak memiliki madharat yang besar seperti pelaksanaan pilkada serentak secara langsung ditengah pandemi covid-19.

\section{SIMPULAN}

Pemilu dan Pilkada adalah salah satu perwujudan dari pelaksanaan kedaulatan rakyat didalam penyelenggaraan pemerintah, dimana rakyat diberikan hak untuk aktif dalam menentukan pemimpinnya. hal ini merupakan amanat dari Pasal 1 Ayat (2) UUD 1954 yang menjeaskan bahwa "Kedaulatan berada ditangan rakyat dan dilaksanakan menurut UndangUndang Dasar”. Namun, pelaksanaan pilkada serentak di tengah pandemi covid-19 ini tentunya menimbulkan berbagai penolakan terutama mengenai keselamatan rakyat ditengah pandemi covid-19, di dalam maqashid syari'ah dijelaskan bahwa pentingnya menjaga agama (Hifdz Ad-Din), menjaga jiwa (Hifdz An-Nafs), menjaga akal (Hifdz Al'Aql), menjaga keturunan (Hifdz An-Nashb) serta menjaga harta (Hifdz Al-Maal).

Selain itu dalam kaidah-kaidah fikih induk (al-qawaid al-asasiyah) dijelaskan bahwa

الضَّرَرِيرًَالْ yang artinya kemudharatan hendaknya dihilangkan. Dalam hal pilkada serentak dimasa pandemi covid-19 ini tentunya haruslah bersikap bijaksana. Memang pilkada serentak adalah sesuatu hal yang harus dilaksanakan dalam negara demokrasi agar tidak ada kekosongan dalam jabatan kepala daerah, sehingga pelayanan pemerintah kepada rakyat tetap berajalan, akan tetapi dampak yang ditimbulkan jika tetap melakukan pilkada serentak di masa pandemi covid-19 ini tidak main-main, mengingat ada jutaan rakyat yang akan beresiko terpapar covid-19 maka daripada itu menolak kemudharatan haruslah didahulukan dengan menunda kembali pilkada serentak dan akibat yang ditimbulkan dari penundaan pilkada serentak tidak lebih besar daripada tetap melaksanakan pilkada serentak di tengah pandemi covid-19 ini, penundaan pelaksanaan pilkada serentak adalah demi menjaga jiwa 
TAHKIM, Jurnal Peradaban dan Hukum Islam. Vol.4 No.l (Maret, 2021) | ISSN : 2597-7962

(Hifdz An-Nafs) rakyat Indonesia dengan dasar kaidah "Menolak kemadharatan didahulukan daripada mengambil manfaat" dan kaidah fikih "Apabila ada dua kerusakan saling berlawanan, maka yang diperhatikan yang lebih besar bahayanya dengan melakukan yang lebih ringan bahayanya". 
TAHKIM, Jurnal Peradaban dan Hukum Islam. Vol.4 No.l (Maret, 2021) | ISSN : 2597-7962

\section{DAFTAR PUSTAKA}

\section{Buku:}

Azhari, Fathurrahman. (2015). Qawaid Fiqhiyyah Muamalah. Banjarmasin: Lembaga Pemberdayaan Kualitas Ummat Banjarmasin.

Ibrahim, Duski. (2019). Al-Qawa'id Al-Fiqhiyah (Kaidah-Kaidah Fiqih). Palembang: Noerfikri.

Muhajir, Noer. (2016). Metodologi Penelitian Kuantitatif. Yogyakarta: Percetakan Raka Sarasin.

Munawwir, Ahmad Warson. (1989). Al-Munawwir (Kamus Arab-Indonesia). Surabaya: Pustaka Progresif.

Nasution, Khoiruddin. (2007). Pengantar Studi Islam. Yogyakarta: AC AdeMIA+TAZAFFA.

ND, Mukti Fajar, and Yulianto Achmad. (2010). Dualisme Penelitian Hukum Normatif Dan Empiris. Yogyakarta: Pustaka Pelajar.

Zaidan, Abdul Karim. (2008). Al- Wajiz 100 Kaidah Fikih Dalam Kehidupan Sehari-Hari, Terj. Muhyidin Mas Rida. Jakarta: Pustaka al-Kautsar.

\section{Jurnal:}

Arifulloh, Achmad. (2016). "Pelaksanaan Pilkada Serentak Yang Demokratis, Damai, Dan Bermartabat.” Jurnal Pembaharuan Hukum 3(3):301-11.

Fahmi, Khairul. (2018). "Pergeseran Pembatasan Hak Pilih dalam Regulasi Pemilu dan Pilkada.” Jurnal Konstitusi 14(4):757-77.

Iqbal, Muhammad. (2018). “Urgensi Kaidah-Kaidah Fikih Terhadap Reaktualisasi Hukum Islam Kontemporer.” EduTech: Jurnal Ilmu Pendidikan Dan Ilmu Sosial 4(2): 21-29.

Kennedy, Richard, and Bonaventura Pradana Suhendarto. (2020). "Diskursus Hukum: Alternatif Pola Pengisian Jabatan Kepala Daerah di Masa Pandemi Covid-19." Jurnal Pembangunan Hukum Indonesia 2(2):188-204.

Permana, Iwan. (2020). "Penerapan Kaidah-Kaidah Fiqih Dalam Transaksi Ekonomi di Lembaga Keuangan Syariah." Tahkim (Jurnal Peradaban dan Hukum Islam) 3(1):17-38. 
TAHKIII, Jurnal Peradaban dan Hukum Islam. Vol.4 No.l (Maret, 2021) | ISSN : 2597-7962

Sacipto, R. (2019). “Tinjauan Wawasan Kaum Milineal Menghadapi Pelaksanaan Pesta Demokrasi.” ADIL Indonesia Journal 1(1): 61-70.

Saputera, Abdur Rahman Adi. (2020). "Menelisik Dinamika dan Eksistensi Fatwa MUI Sebagai Upaya Mitigasi Pandemi COVID-19." Tahkim (Jurnal Peradaban dan Hukum Islam) 3(2):59-78.

Widianingsih, Yuliani. (2017). "Demokrasi dan Pemilu di Indonesia: Suatu Tinjauan Dari Aspek Sejarah dan Sosiologi Politik. ”Jurnal Signal 5(2): 1-19.

\section{Website:}

https://republika.co.id/berita/qi2wlw328/pelajaran-dari-klaster-pemilu-sabah diakses pada hari Selasa tanggal 13 Oktober 2020 pukul 10.36 WIB 